\title{
ALTALAJLAZÍTÓ MUNKAESZKÖZ KINEMATIKAI ÉS DINAMIKAI VIZSGÁLATA
}

\section{RESEARCH ABOUT THE KINEMATICS AND THE DYNAMICS OF THE SUBSOILER'S WORKING TOOL}

\author{
Pásztor Judit ${ }^{1}$, Forgó Zoltán ${ }^{2}$ \\ ${ }^{1}$ Sapientia EMTE, Müszaki és Humántudományok Kar, Cím: 540485, Románia, Ma- \\ rosvásárhely/Koronkai Segesvári út 1C, postacim: O.p. 9, C.p. 4, tel: +40 265206 \\ 210,fax: +40265 206 211, levelezésicim:pjudit@ms.sapientia.ro \\ ${ }^{2}$ Sapientia EMTE, Müszaki és Humántudományok Kar, Románia, Cím: 540485, \\ Románia, Marosvásárhely/Koronkai Segesvári út 1C, postacím: O.p. 9, C.p. 4, , tel: \\ +40265206 210, fax: +40265206 211, levelezési cím: zforgo@ms.sapientia.ro
}

\begin{abstract}
The preparation of the seedbed represents an essential work for the growth and development of plants. It is an important consumer of energy. The subsoiler is meant to carry out the basic works in the cultivated land. In this paper we study the kinematics and the dynamics of subsoiler's tillage tools.

Keywords: subsoiler, kinematics, dinamics

\section{Összefoglalás}

A talaj előkészítése nagyon fontos a termesztett növények számára. A gépek munkája hatással van a talaj fizikai-mechanikai tulajdonságaira, közvetve a növényekre, ezért megválasztásuk és üzemeltetésük nagy körültekintést igényel. Az altalajlazító a talajművelés alapgépe. Dolgozatunkban az altalajlazító munkaeszköz kinematikai egyenleteit határozzuk meg, amelyek segítségével dinamikai vizsgálatokat végzünk.
\end{abstract}

Kulcsszavak: altalajlazító, kinematika, dinamika

\section{Bevezetés}

A talajmüvelés mechanikai beavatkozás. Célja a termesztendö növény számára kedvező talajállapot kialakítása.

A talajmüvelés alapmüveletekre, magágy-előkészítésre és tarlómunkákra osztható. Az alapmüveletek a legmélyebb beavatkozások, amelyek forgatással vagy forgatás nélkül történhetnek [1].

Az altalajlazító az a munkagép, amely a mélyebb talajrétegek lazítását forgatás nélkül valósítja meg. Így a talaj művelt rétegét mélyíti, az alsó réteget lazítja, javítva a víz- és levegőháztartást. Elősegíti a mély gyökérzetű növények jobb fejlődését. Az eketalpbetegség megelőzésére és megszüntetésére is alkalmas.

$\mathrm{Az}$ altalajlazító munkagépeket a talajművelő eszközeik mozgásviszonyai, munkavégzésük jellegzetessége alapján két fó csoportba lehet sorolni. Passzív és aktív művelöeszközökkel felszerelt altalajlazítókat különböztethetünk meg.

Passzívnak tekintjük azt az eszközt, amely a munkagépre mereven van rögzítve, a kerethez képest önállóan nem mozdul el, csak a traktor által meghatározott fómoz- 
gást végzi (1a. ábra). Aktív talajmüvelő eszköznek tekintjük azt a müvelőelemet, amely a gép főmozgása, a haladó mozgás mellett kényszerhajtás következtében mellékmozgást végez (1b-c. ábra). E két mozgás együttes hatására jön létre az elérni kívánt talajmunka [3].

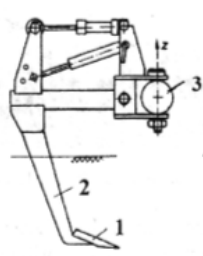

a.

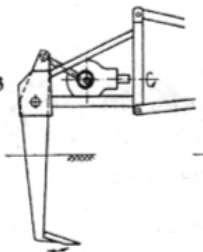

b.

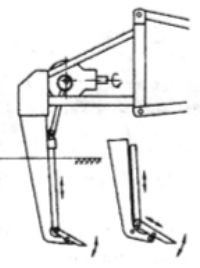

c.
1. ábra. Altalajlazitó szerszámok:

a- passziv müvelöszerszám,

$b$ - rezgö müvelöszerszám,

c - lengö müvelöszerszám [4]

Dolgozatunkban a lengőmozgást végző altalajlazító eszközt vizsgáljuk.

A gépüzemeltetés mindenkori célja a növény által igényelt magágy lehető legkevesebb menetszámmal és kedvező energiafelhasználással való biztosítása. A mozgáspályák matematikai modellezése alapján tanulmányozható a munkaeszköz mozgása. A kinematikai egyenletek alapján felírhatók a munkaeszköz dinamikai egyenletei. A kinematikai és dinamikai egyenletek segítségével számolható a munkagép energiaigénye.

\section{Kidolgozás}

\subsection{Az altalajlazító munkaeszköz ki- nematikai egyenletei}

Az altalajlazító felépítését az 2. ábra szemlélteti.

Az 1-es szerszámszár előtt mozog a 2-es függesztőkar. Hajtása a 4-es térben kitérő tengelyről történik, amely az erőgép teljesítményleadó tengelyéről kapja a hajtását lassító áttételen keresztül. Az 5-ös TLT tengely fordulatszáma egyezményes, 540 ford/min. Az AB függesztőkar a 3-as BD szerszámot mozgatja, amely a $\mathrm{C}$ pont körül lengő mozgást végez [7].

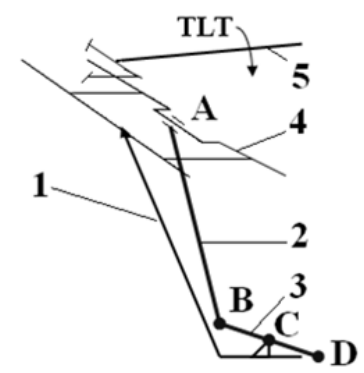

2. ábra. Altalajlazitó munkaeszköze

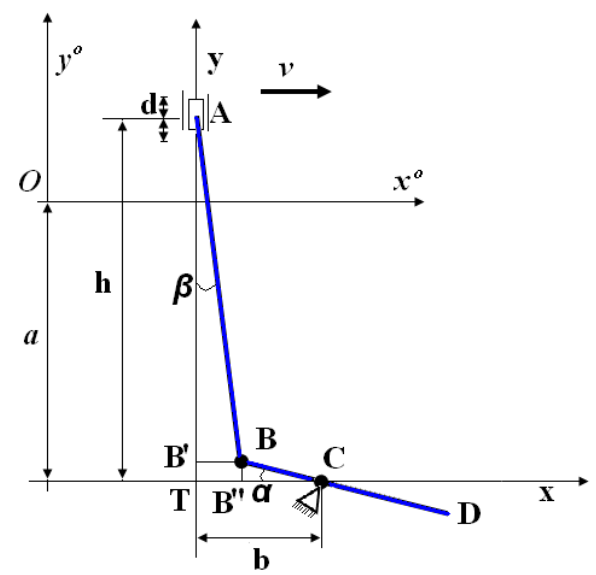

3. ábra. Altalajlazitó mechanizmusa

$D\left(x_{D}, y_{D}\right)$ pont a lazítószerszám hegyét jelképezi. A vontatás hatására a lazítószerszám és szerszámszár elvágja, hasítja a talajt. Az elhasított talajban a szerszám ékként halad előre, a talaj megemelkedik a szerszám felületén, majd lemaradva az ék után szétaprózódik. Ezáltal megnő a fajlagos térfogata, javul a talaj levegö- és vízháztartása. A lengőmozgás hatására a hasítás elött széttöredezik, lazítódik a talaj. Ebben a lazított talajban könnyebb a szer- 
számszár és szerszám előrehaladása, így csökken a munkagép vonóeröigénye 4. ábra. A 4. ábrán követhető, hogy az átmunkált talajkeresztmetszet az $a$ munkamélységtől függ. A talaj belső surlódásának hatására a lazítás $b_{0}=2 a$ szélességben érzékelhetö [1], [2].

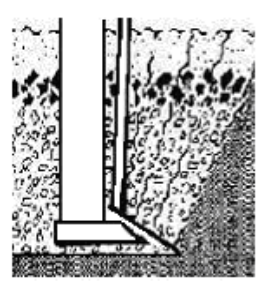

a.

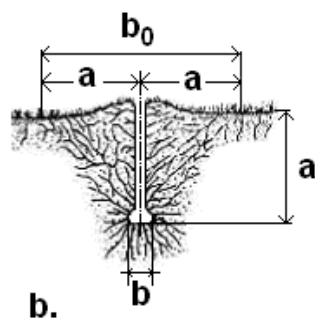

b.

4.ábra. Lazitószerszám munkája:

$a$ - az elörehaladással párhuzamos síkban,

$b$ - az elörehaladásra meröleges síkban

Az lazítóhegy, $D\left(x_{D}, y_{D}\right)$ pont, kinematikai egyenletei az $x T y$ mozgó koordináta rendszerben a következő összefüggésekkel adhatók meg, [5], [6]:

$$
\begin{gathered}
A\left\{\begin{array}{l}
x_{A}=0 \\
y_{A}=h+d \sin \varphi, \\
\varphi=\omega \cdot t
\end{array}\right. \\
B\left\{\begin{array}{l}
x_{B}=b-B C \cdot \cos \alpha \\
y_{B}=B C \cdot \sin \alpha
\end{array},\right. \\
D\left\{\begin{array}{l}
x_{D}=b+C D \cdot \cos \alpha \\
y_{D}=-C D \cdot \sin \alpha
\end{array},\right.
\end{gathered}
$$

ahol $\omega$ a hajtótengely szögsebessége, $\mathrm{rad} / \mathrm{s}$; $t$ az idö, s; $b, h, d$ [8]konstrukciós adatok, mm, $\alpha$ és $\beta$ müködést jellemző adatok, 3. ábra.

Az ABB' és CBB', derékszögű háromszögek szögfüggvényei segítségével elvégezzük a megfelelő behelyettesítéseket, és az alábbi össszefüggésekhez jutunk:
$\left\{\begin{array}{l}y_{A}-B C \cdot \sin \alpha=A B \cdot \cos \beta \\ b-B C \cdot \cos \alpha=A B \cdot \sin \beta\end{array}\right.$.

A (4) összefüggéseket összevonjuk:

$$
\begin{aligned}
& y_{A}^{2}+b^{2}+B C^{2}-2 y_{A} \cdot B C \sin \alpha- \\
& -2 \cdot b \cdot B C \cdot \cos \alpha=A B^{2}
\end{aligned}
$$

Az (5) egyenlet megoldásához trigonometriai azonosságokat használunk, amelyek az alábbi másodfokú egyenlethez vezetnek [6], [9]:

$$
(n+p) \cdot \operatorname{tg}^{2} \frac{\alpha}{2}-2 m \cdot \operatorname{tg} \frac{\alpha}{2}+p-n=0
$$

ahol:

$$
\begin{aligned}
& m=-2 y_{A} B C \\
& n=-2 b \cdot B C \\
& p=A B^{2}-y_{A}^{2}-b^{2}-B C^{2} .
\end{aligned}
$$

A (6) egyenlet megoldásai közül az $\alpha$ hegyesszög értékeit választjuk.

$$
\operatorname{tg} \frac{\alpha}{2}=\frac{m \pm \sqrt{m^{2}+n^{2}-p^{2}}}{n+p}
$$

Az $\alpha$ szög ismeretében meghatározhatók a lengőmozgást végző $D\left(x_{D}, y_{D}\right)$ pont kitérései és pályagörbéje, amelyek az 5., 6., 7. ábrán követhetök.

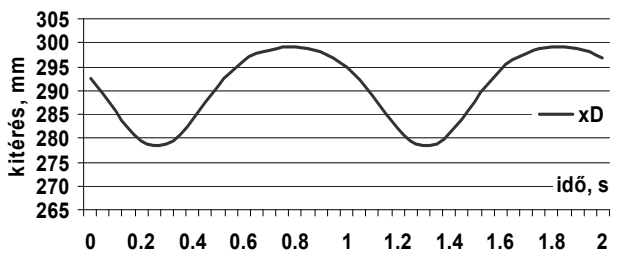

5.ábra. Aktív talajlazitó vizszintes kitérése 


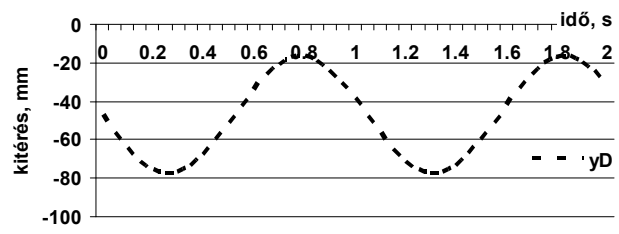

6. ábra. Aktív talajlazitó függőleges kitérése

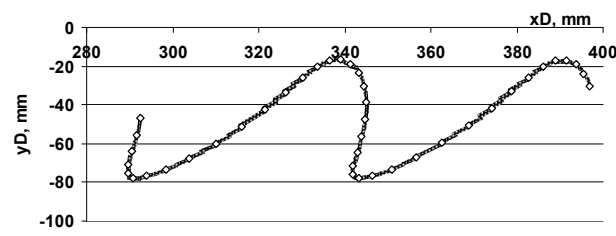

7. ábra. Aktiv talajlazitó szerszám pályája

A $D\left(x_{D}, y_{D}\right)$ pont pályagörbéje az ${ }^{o} x O^{o} y$ álló koordináta-rendszerben a következő transzformációs matrixszal határozható meg:

$$
D_{x O y}=\left(\begin{array}{cccc}
1 & 0 & 0 & v \cdot t \\
0 & 1 & 0 & -a \\
0 & 0 & 1 & 0 \\
0 & 0 & 0 & 1
\end{array}\right),
$$

ahol $v$ a munkagép sebessége, $\mathrm{mm} / \mathrm{s} ; a$ a munkamélység, mm. A jelölések a 3. ábrán követhetők.

A D pont kinematikai egyenletei az álló koordináta-rendszerben az alábbiak:

$$
D_{x O y}\left\{\begin{array}{l}
{ }^{0} x_{D}=b+C D \cdot \cos \alpha+v \cdot t \\
{ }^{0} y_{D}=-C D \cdot \sin \alpha-a
\end{array}\right.
$$

Az aktív talajlazító szerszám pályája mélylazítás közben a 12. ábrán követhető. Megállapítható, hogy a mozgásegyenletek leírják a várt, a szakirodalomban fellelhető ábrát, így a kinematikai egyenletek helyeseknek tekinthetök, és alkalmasak a további vizsgálatok elvégzéséhez.

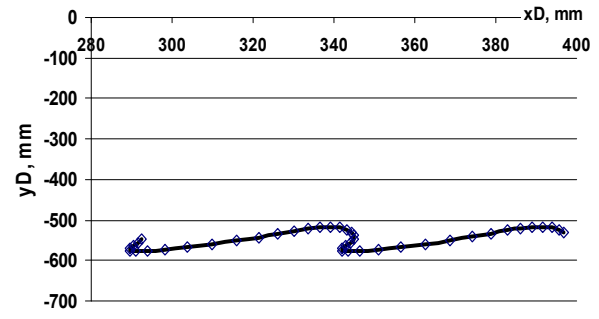

8. ábra. Aktív talajlazitó szerszám pályája munka közben

\subsection{Az altalajlazító munkaeszközének dinamikai egyenletei}

A dinamikai modellek megalkotásához felhasználjuk az $D\left(x_{D}, y_{D}\right)$ lazítószerszám csúcsának mozgásegyenleteit.

A dinamikai modellek a következők:

- sebességmodellek (11);

- gyorsulásmodellek (12).

$$
\begin{aligned}
& { }^{o} \dot{x}_{D}=v_{x D}=-C D \sin \alpha \cdot \dot{\alpha}+v \\
& { }^{0} \dot{y}_{D}=v_{y D}=-C D \cos \alpha \cdot \dot{\alpha} \\
& a_{x D}=-C D \cos \alpha \cdot(\dot{\alpha})^{2}-C D \sin \alpha \cdot \ddot{\alpha} \\
& a_{y D}=C D \sin \alpha \cdot(\dot{\alpha})^{2}-C D \cos \alpha \cdot \ddot{\alpha}
\end{aligned}
$$

A (11) és (12) összefüggésekben szereplő $\dot{\alpha}$ meghatározása az (1) és (5) összefüggések deriválásával történik:

$$
\begin{aligned}
& \dot{y}_{A}=d \cdot \omega \cdot \cos \varphi \\
& y_{A} \dot{y}_{A}-B C \cdot \dot{y}_{A} \sin \alpha- \\
& -B C \cdot y_{A} \dot{\alpha} \cdot \cos \alpha+B C \cdot b \cdot \dot{\alpha} \sin \alpha=0
\end{aligned}
$$

A (13) és (14) egyenletekből kifejezhető az $\dot{\alpha}$, az $\alpha$ és $\varphi$ szögek függvényében:

$$
\dot{\alpha}=\frac{d \omega \cdot \cos \varphi \cdot[B C \sin \alpha-(h+d \sin \varphi)]}{[(h+d \sin \varphi) \cdot \cos \alpha-b \cdot \sin \alpha)] \cdot B C}=\frac{M}{N}
$$


A (15) kifejezés deriválásával kiszámítható az $\ddot{\alpha}$ összefüggése:

$$
\ddot{\alpha}=\frac{\dot{M} \cdot N-M \cdot \dot{N}}{N^{2}}
$$

ahol $M$ a (15) kifejezés számlálója és $N$ a kifejezés nevezője. $M$ és $N$ idő szerinti deriváltjai:

$$
\begin{aligned}
& \dot{M}=-d \varpi^{2} \sin \varphi\left(B C \sin \alpha-y_{A}\right)+ \\
& +d \varpi \cos \varphi\left(B C \cdot \dot{\alpha} \cdot \cos \alpha-\dot{y}_{A}\right) \\
& \dot{N}=B C\left(b \cdot \dot{\alpha} \cdot \cos \alpha-\dot{y}_{A} \cos \alpha+\right. \\
& \left.+y_{A} \cdot \dot{\alpha} \cdot \sin \alpha\right)
\end{aligned}
$$

\section{Az altalajlazító-szerszám gyorsu-} lásai a (12) összefüggésekkel számolhatók és a 9.ábrán figyelhetők meg.

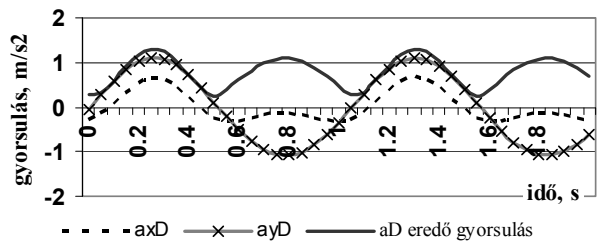

9. ábra. Altalajlazitószerszám gyorsulása

Az altalajlazító pályáján két szakasz különíthetö el. Az $a_{y D}$ grafikonját követve:

- új helyzetbe vonulás-lassítás, $(0,5 \mathrm{~s}-1 \mathrm{~s})$,

- gyorsulás-emelés, $(1 \mathrm{~s}-1,5 \mathrm{~s})$.

A szerszám tömegének és gyorsulásának ismeretében számolható a szerszámra ható erők nagysága, (18).

$$
\begin{aligned}
& \vec{R}_{X}=m \cdot a_{x D} \\
& \vec{R}_{y}=m \cdot a_{y D}
\end{aligned}
$$

Az erők ismeretében vizsgálható a lazítószerszámra ható erők feladata, 10.ábra. $F t$ vágóerő a szerszám mentén jelentkezik, az $R_{x}$ erőkomponens a szerszám ékfelületével párhuzamos összetevője.

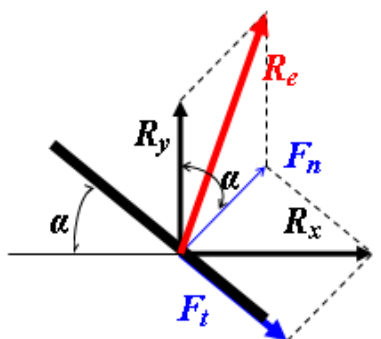

10.ábra. A lazitószerszámra ható erők

A föggőleges $R_{y}$ erő az ékfelületre merőleges $F_{n}$ összetevővel együtt az emelést biztosítja. Eredőjük az $R_{\mathrm{e}}$ erő, amely a (19) egyenlet harmadik tagjával számítható.

$$
\begin{aligned}
& F_{t}=R_{x} \cos \alpha \\
& F_{n}=R_{x} \sin \alpha \\
& R_{e}=\sqrt{R_{y}^{2}+F_{n}^{2}-2 R_{y} F_{n} \cos \alpha}
\end{aligned}
$$

$\mathrm{Az} R_{o ̈ s s z}$ az $R_{x}$ és $R_{y}$ erők eredője:

$$
R_{\text {össz }}=\sqrt{R_{x}^{2}+R_{y}^{2}} .
$$

Az erők fajlagos értékei a 11.ábrán láthatók.

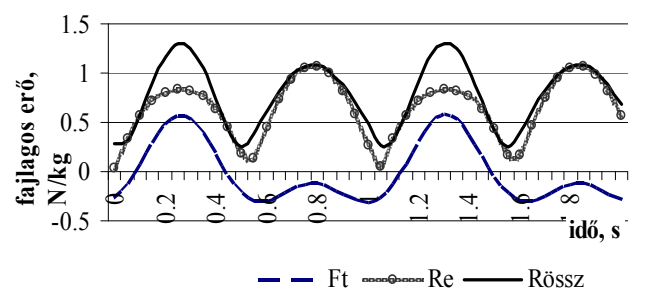

11. ábra. Talajlazitó szerszámra ható erők fajlagos értékei

\section{Következtetések}

- $R_{X}$, vízszintes komponens a talaj vágására és a talaj emelésére fordítódik.

- $R_{Y}$, függőleges komponens a kivágott talajszeletet emeli, a lazítást végzi. 
- A fajlagos erők és az alkotórészek tömegének ismeretében számítható a munkagép hajtóerő- és teljesítményigénye.

- Az aktív munkaeszközök eröteljesen elölazítják a talajt, így kevesebb a munkagép vonóerőigénye, kisebb a vontatásnál jelentkező csúszási veszteség, ezért nedvesebb talajviszonyok közt is alkalmazható.

- A talajlazítók az energiatakarékos talajművelés gépei, a talaj lazítását forgatás nélkül végzik, így a vonóerőigény lényegesen kisebb, mint az azonos talajkeresztmetszetet átmunkáló ekéké.

- A kinematikai és dinamikai egyenletek további kutatások alapjául szolgálnak.

\section{Szakirodalmi hivatkozások}

[1] Brătucu Gh.: Tehnologie agricolă. Universitatea Transilvania, Braşov, 1999.

[2] Căpăţână I.: Aspecte teoretice privind dinamica sistemului tractor-subsolier. INMATEH III, Bucureşti, 2007. 183-191.

[3] Láng Z.: A zöldség-, dísznövény- és szaporitóanyag - termesztés berende-zései és gépei. Mezőgazda Kiadó, Budapest, 1999, 53-54;

[4] Naghiu Al.: Maşini şi instalaţii agricole. Vol. I. Editura Risoprint, Cluj-Napoca, 2004.

[5] Máté, M.: Müszaki mechanika - kinematika. EME Kiadó, Kolozsvár, 2010.

[6] Papp I.: Mechanizmusok elmélete. Scientia Kiadó, Kolozsvár, 2010.

[7] Pásztor J., Forgó Z.: Ásógép kinematikája és munkaminöségi mutatóinak vizsgálata növényházban. Müszaki Szemle, Kolozsvár, 2009. 310-314.

[8] Ripianu A.: Mecanica tehnică. Ed. Didactică şi Pedagogică, București, 1972. 210;

[9] Sztachó-Pekáry I., Szendrő P.: Példák mezögazdasági géptanból. Mezőgazdasági Szaktudás Kiadó, Budapest, 1997. 